\title{
CONJUNCTIVE USE OF GROUNDWATER AND SURFACE WATER IN A PART OF HIRAKUD COMMAND AREA
}

\author{
Sandeep Samantaray ${ }^{1}$, Ashutosh Rath ${ }^{2}$, Prof. Prakash Chadra Swain ${ }^{3}$ \\ Department of Civil Engineering, VSS University of Technology, Burla 768018, Odisha, India \\ samantaraysandeep963@gmail.com \\ erashutoshrath@gmail.com \\ pcswain.vssut@hotmail.com
}

\begin{abstract}
The approach towards integrated or conjunctive use of surface and groundwater resources and takes account of social economic and environmental factors. Groundwater modelling is a tool that can help to analyze many groundwater problems. Visual MODFLOW software uses a finite difference method to solve the equation. This study aims to reveals that the suitability of MODFLOW software under various hydro geologic conditions. To predict the system behaviour, Visual MODFLOW is the easy to use modelling environment for two dimensional and three dimensional groundwater flows and contamin and transport simulations. Here average runoff, rainfall and groundwater table fluctuation of the Hirakud Command Area has taken into consideration for the part of Conjunctive use. Senhapali distributary has been taken into consideration as the excess water (waterlogged areas) present in this can be used in the area having less water with help of Visual MODFLOW by the river boundaries, particles, and velocity and cell inspector. A steady state groundwater flow simulation was carried out using Visual MODFLOW software. It indicated the topography controls groundwater flow and the base flow to the river is an important factor moderating groundwater movement in the Command Area. Lastly conjunctive use has been done by inserting bore wells as a substitute for flow irrigation and supply of water to the communities and trees are also planted so as for controlling of water logging and dry salinity.
\end{abstract}

Keyword - Modflow, Ground water fluctuation, Hirakud command area.

\section{INTRODUCTION}

Groundwater modelling involves simulation of aquifer and its response to various input/output systems. Groundwater Models have been applied to investigate a wide variety of hydro geologic conditions. More recently, groundwater models are being applied to predict the fate and transport of contaminants for risk evaluation. The use of groundwater models to simulate groundwater flow and contaminant transport has greatly increased over the past decade. Groundwater models represent or approximate a real system and are tools that help in the organization and understanding of hydro geologic data or the prediction of future hydro geologic events. Models are not a substitute for field investigations, but should be used as supplementary tools. Results are dependent on the quality and quantity of the field data available to define input parameters and boundary conditions.Conjunctive water use has been a water resource development tool since to 1960s. Concerns over the technical mobilisation of more water have shifted into serious considerations on water allocation as water resources are seen to be reaching finite limits. It has also been of specific interest in many regional rural development plans. It has also become of increasing interest in irrigation scheme management. Conjunctive use became a component of World Bank irrigation development policy in the early 1980s, in response to increases in agricultural production. Conjunctive use can contribute to improved agricultural performance, sustainability and equity. An improved water supply can increase output by facilitating the irrigation of additional land and permitting increased irrigation intensities.

Arora and Goyal (2002) carried out a systematic study for the factors responsible for water-logging and soil salinity in Hanumangarh and Sri-Ganganagar districts of Rajasthan, India. Sethi et al., (2002) worked on Optimal Crop Planning and Conjunctive Use of Water Resources in a Coastal River Basin where they went through the implementation of models such as groundwater balance model and optimum cropping and groundwater management model to determine optimum cropping pattern and groundwater allocation from private and government tube wells according to different soil types (saline and non-saline), type of agriculture (rained and irrigated) and seasons (monsoon and winter). Rao et al. (2004) developed a regional conjunctive use model for a near-real deltaic aquifer system, irrigated from a diversion system with reference to hydro climatic conditions prevalent in the east coastal delta of India. Safavi et al., (2010) published a paper on SimulationOptimization Modelling of Conjunctive Use of Surface Water and Groundwater. Kumar and Sinha (2009) 
carried out a groundwater simulation study using MODFLOW package in Hirakud Irrigation Command area, Odisha. Marques et al., (2010) applied the two stage stochastic quadratic programming to optimize conjunctive use operations of groundwater pumping and artificial recharge with farmer's expected revenue and cropping decisions. Jaffari and Das (2013) used Integrated Conjunctive Use Model where it was formulated as an allocation model which was a constrained non-linear programming problem. Kumar et al. (2015) used Integrated Modelling Framework to Evaluate Conjunctive Use Options in a Canal Irrigated Area- ACROPWAT 8.0 model Approach a simple, integrated framework was developed and implemented to characterize and quantify interactions between surface water and groundwater in a canal irrigated area.

\section{METHEODOLOGY}

This chapter mainly deals with the method of using Visual MODFLOW in pumping well criteria as a great achievement toward the conjunctive use of groundwater and surface water which will help in extracting water while there is no water in month of dry season or in the time of need.

\subsection{Modelling tool}

MODFLOW package simulates groundwater fluctuation of each cropping season of the year and allows studying the waterlogging scenario of the area. The mathematical background of MODFLOW describes threedimensional partial differential equation governing unsteady movement of groundwater of constant density through porous earth material under equilibrium condition in a heterogeneous anisotropic medium by:

$$
\frac{\partial}{\partial x}\left(K_{x x} \frac{d h}{d x}\right)+\frac{\partial}{\partial y}\left(K_{x y} \frac{d h}{d y}\right)+\frac{\partial}{\partial z}\left(K_{z z} \frac{d h}{d z}\right)-W=S_{s} \frac{\partial h}{\partial t}
$$

\section{Where,}

$\mathrm{K}_{\mathrm{xx}}, \mathrm{K}_{\mathrm{yy}}, \mathrm{K}_{\mathrm{zz}}$ : hydraulic conductivity along major axes $\left[L T^{-1}\right]$,

$\mathrm{h}$ : potentiometric head [L],

$\mathrm{W}$ : volumetric flux per unit volume and represents sources and/or sinks of water $\left[T^{-1}\right]$,

Ss: specific storage of the porous material $\left[L^{-1}\right]$

t: time [T].

\section{1 visual modflow}

\subsubsection{Description of visual modflow}

Visual MODFLOW is the most complete and easy-to-use modelling environment for Practical applications in three-dimensional groundwater flow and contaminant transport Simulations. This fully-integrated package combines MODFLOW, MODFLOWSURFACT, MODPATH, Zone Budget, MT3Dxx/RT3D, MGO, and Win PEST with the most intuitive and powerful graphical interface available. The logical menu structure and easyto-use graphical tools allow us the following:

- Easily dimension the model domain and select units

- Conveniently assign model properties and boundary conditions

- Run the model simulations

- Calibrate the model using manual or automated techniques

- Optimize the pumping well rates and locations

- Visualize the results using 2D or 3D graphics

2.1.2 model design and input

Section 1:Dimension and Build a Model Grid

Inthis section certain dimensions have been taken in respect with this a model grid .

Section 2: Input Model Properties and Boundary Conditions

In this section will help in building a groundwater flow model with Visual MODFLOW is to begin graphically assigning the model parameters .Here the data provided indicates the conductivities and soil properties porosity of the study area.

Section 3: Assigning particle tracking locations:

$>$ Particle tracking model are specifically designed to monitor the particle pathways and fate of contaminant sources.

> MODPATH is a particle tracking post-processing package that was developed to compute threedimensional flow paths using output from steady state or transient ground-water flow simulations by MODFLOW. 
DODPATH uses a semi-analytic particle tracking scheme that allows an analytical expression of the particle's flow to be obtained within each finite-difference grid cell.

> Particle tracking analysis was used to track lines of particles and determine the preferred contaminant exposure pathways from recharge area near excess water area or waterlogged area to deficit area and discharge points of supply wells, and to evaluate particle travel times of the cycle

\subsubsection{Visualization of model results}

Visual mudflow is powerful post processing tools have been specifically designed for optimizing the display of groundwater flow and contaminant transport simulations. The post processing of the results includes steadystate or transient contouring of Equipotential, head differences between layers, head fluxes between layers, drawdown, water table elevation and MT3D concentrations.

\subsubsection{Simulating a pumping well}

To determine the pumping rate required and to capture the existing plume and prevent any further off site mitigation of the groundwater plume. For a well certain data's are taken for the pumping purposes. It is estimated that design, approval and installation of the pump-and-treat remediation system will take a minimum of one year to complete.

\section{METHEODOLOGY}

The present experiment is carried on one of the canals of the Hirakud canal system. This area is situated at the western part of the Odisha from $21^{\circ} 05^{\prime} \mathrm{N}$ to $21^{\circ} 55^{\prime} \mathrm{N}$ latitude and $83^{\circ} 55^{\prime} \mathrm{E}$ to $84^{\circ} 05^{\prime} \mathrm{E}$ longitude. Hirakud Reservoir is a multipurpose scheme intended for flood control, irrigation and power generation. The Dam is built across river Mahanadi at about $15 \mathrm{~km}$ upstream of Sambalpur town in the state of Odisha. The Hirakud canal system consist of three canal system namely Bargarh Main canal, Sason main canal, Sambalpur distributary. The Sambalpur distributary emerges from the left dyke of the Hirakud Reservoir. The Senhapali distributary, emerges out of the power channel of the Hirakud system to provide irrigation to Chaunrpur, Senhapali, Berhampura, Baguria, Bakbira, Jharpali, Tihikipali. The CCA of Senhapali distributary is found to be 1896.67 ha. Due to lack of maintenance and irregular rainfall the irrigation command varies from year to year.

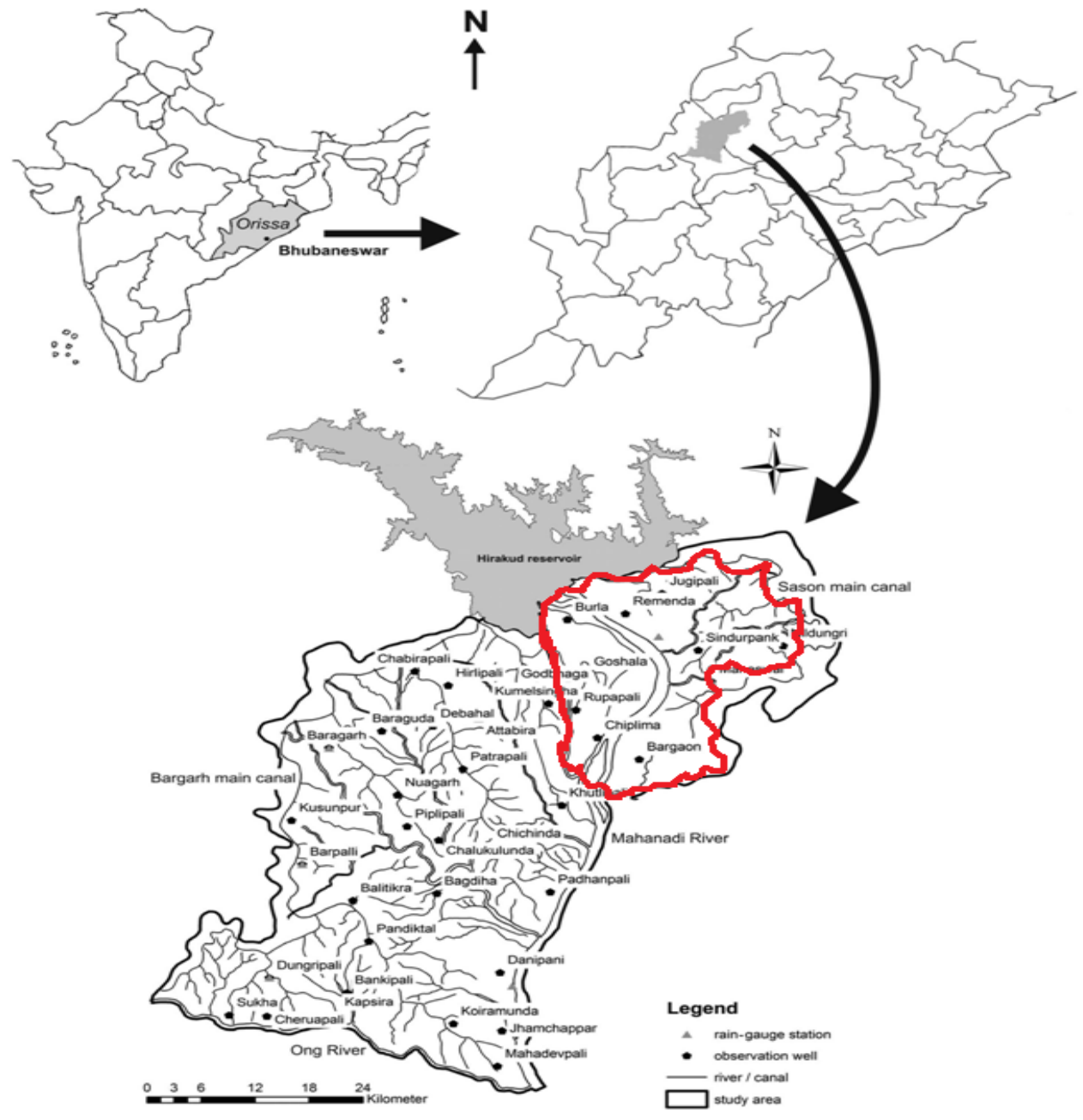

Fig. 1 Command area of Hirakud Dam and its canal system 


\section{RESULTS AND DISCUSSIONS}

Any phenomenon, which produces pressure change within an aquifer, results into the change of ground water level. These changes in ground water level can be a result of changes in storage, amount of discharge and recharge, variation of stream stages and evaporation. External loads such as tides, trains, atmospheric pressure and earthquake are born in part by the ground water of confined aquifers. Hence they affect piezo metric levels. The general consideration is that due to any reason if the aquifer pressure rises above the atmospheric pressure an up levelling in ground water level results and vice- versa.

4.1 results from runoff data

Runoff is directly or indirectly affecting both the surface water and groundwater .So runoff is regarded as most important parameter in assessment of groundwater flow modelling. The data collected for the average runoff of Hirakud Reservoir System has been used for the conjunctive use as per the groundwater and surface water interaction. Data's represent the prior utilization of excess water towards deficit area where there is a prime use of water for the irrigation and supply purpose as per the development of the ecosystem is being concerned.

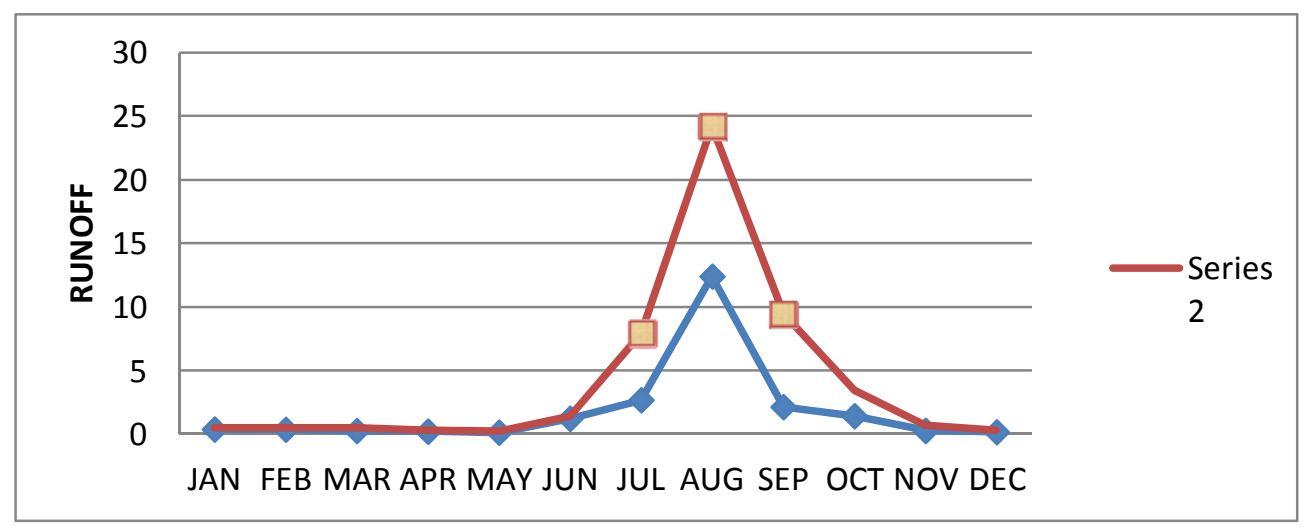

Fig. 2 Comparison between runoff values of 2004 and 2014.

Comparing the values of Average Runoff Data between 2004 and 2014, its shows that August month carry the peak of the two years. It means that during this period of month the ground water increase and thus the excess water can be used as a part in conjunctive use of groundwater to surface water, through Pumping wells and Bore wells. This three months July, August and September are the only three months to store the excess water and prevent the area from being water logged.

\section{2 results from groundwater table fluctuation}

Water levels in aquifers reflect a dynamic balance between groundwater recharge, storage and discharge. If recharge exceeds discharge, the volume of water in storage will increase and water level will rise: if discharge exceeds recharge, the volume of water in storage will decrease and water level will fall. Because recharge and discharge are not distributed uniformly in space and time, groundwater level are continuously rising or falling to adjust to the resulting imbalances. Water levels in wells reflect these changes and provide the principal means of tracking changes in ground water storage over time. Water-level measurements also provide insight into the physical properties that control aquifer recharge, storage, and discharge since this factors affect the timing and intensity of responses to hydrologic stresses such as precipitation and pumping.

From the data that has been collected from Master Control Room, Burla shows that there is a fluctuation of water level between the pre monsoon and post monsoon from 1996 to 2015. Comparing the rainfall of different areas, the high water logged areas and water deficit areas can be found out. Here pumping wells are needed for the extraction of excess water from this areas to the deficit areas. This can be used for the irrigation purposes. 


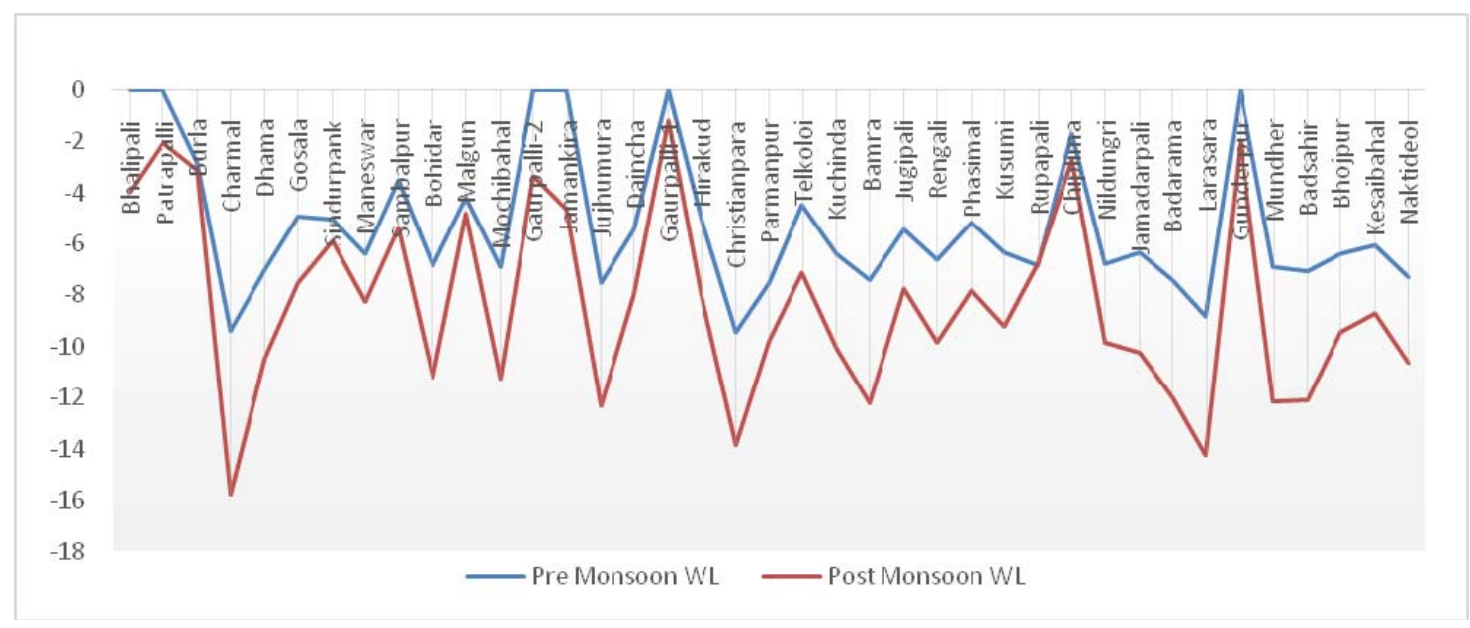

Fig. 3 Groundwater table fluctuation of 2004

Here in this fig.3, it has been seen that areas under Hirakud Command Area such as Bhalipali, Burla, Gaurpalli2, Jujhumura, Gaurpalli-1, Christianpara and Mundher are observed to be highest water level among all areas. Here the conjunctive use of groundwater and surface water is recommended as excess water are present for bore wells which will use the extra water to store and supply in irrigation purposes as a substitute for flow irrigation..

4.3 fluctuation data of 2014

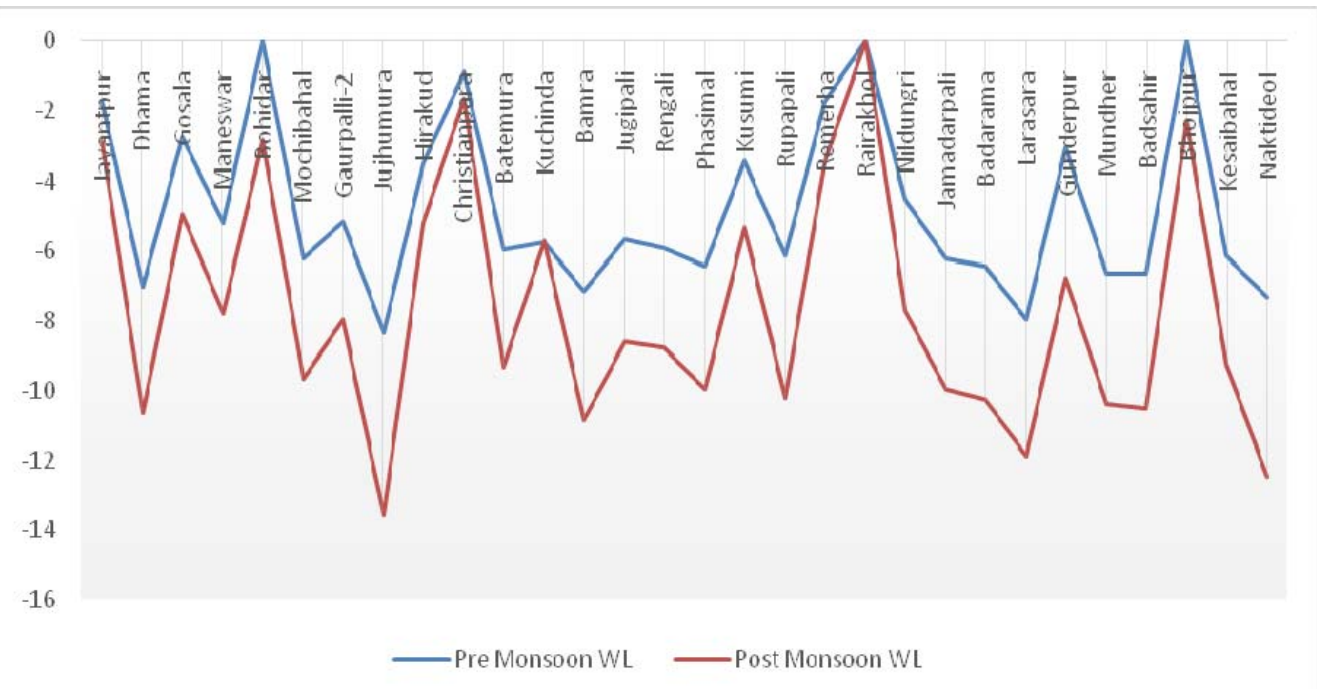

Fig. 4 Pictorial representation of groundwater table fluctuation of 2014

Here in this figure it has been observed that Bohidar, Christianpara, Rairakhol and Bhojpur were considered as high water level. In this case conjunctive use of groundwater and surface water is recommended for bore wells so as for the use of extra water so as per the use is concern in the irrigated area .

\subsection{Results from visual modflow}

The computed groundwater level contours are following the trend of observed groundwater levels. The groundwater velocity vectors indicate the predominant flow towards the power channel of the proposed part of the Hirakud Command Area and present the maximum groundwater velocity as excess amount of water is present in this region. The Computed Groundwater table and the velocity vectors are showing the major groundwater circulation route. This part of Hirakud Command Area has been divided in two cells (Inactive cells for the deficit area and active cells for the excess water at the watershed) to assess the contribution for the groundwater flow process. 


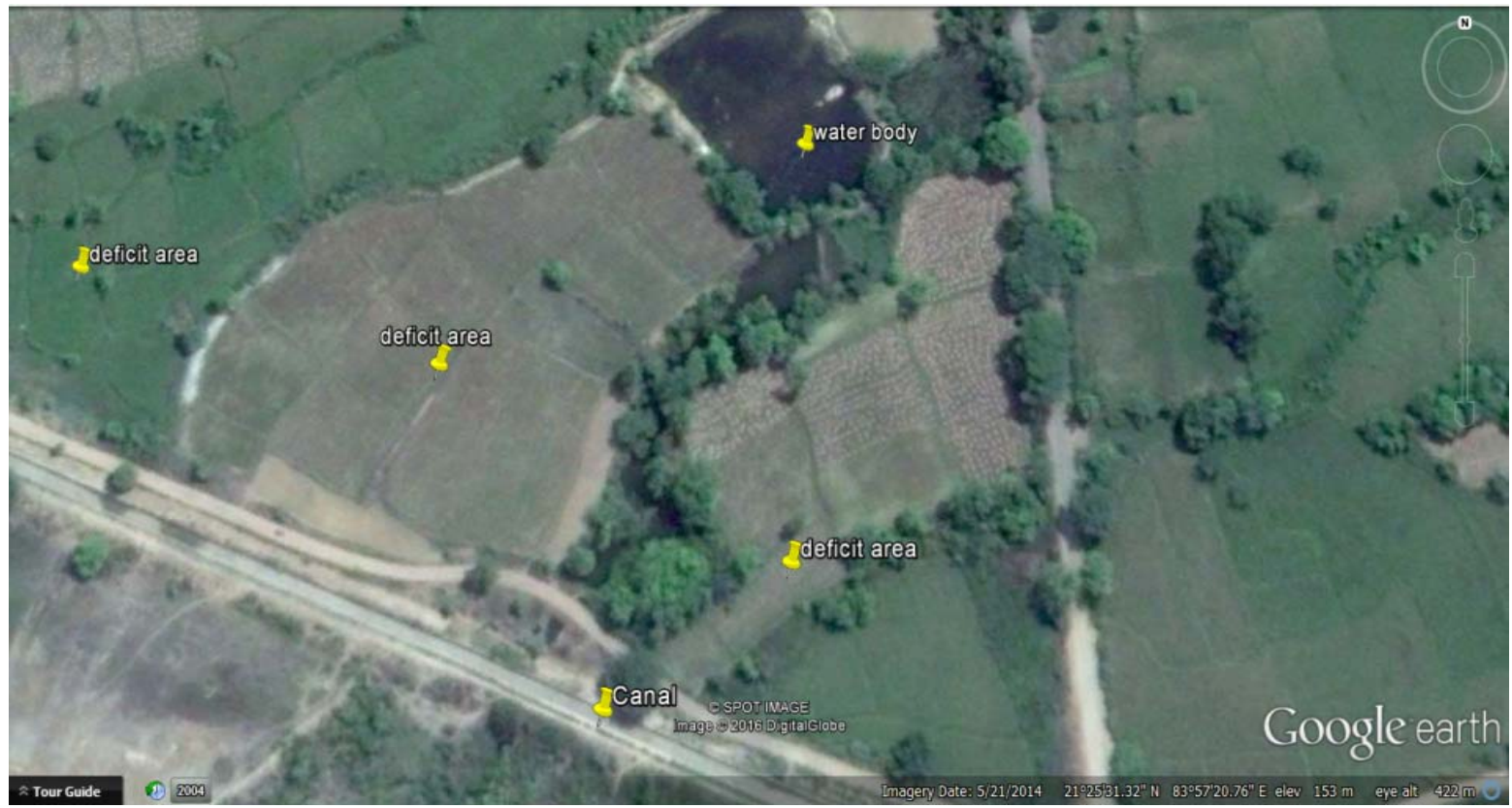

Fig. 5 Imagery view of a area of the Senhapali Distributary.

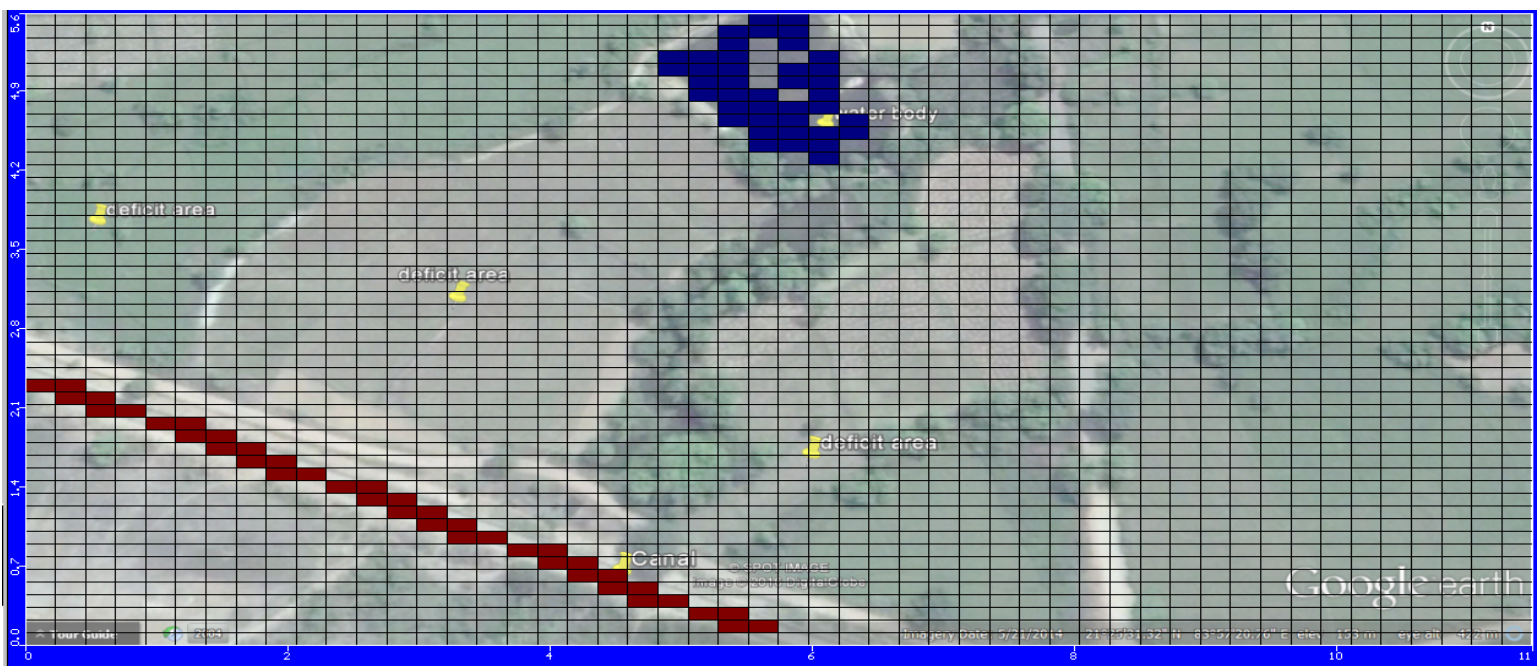

Fig. 6 Constant head and river boundary conditions in the flow model

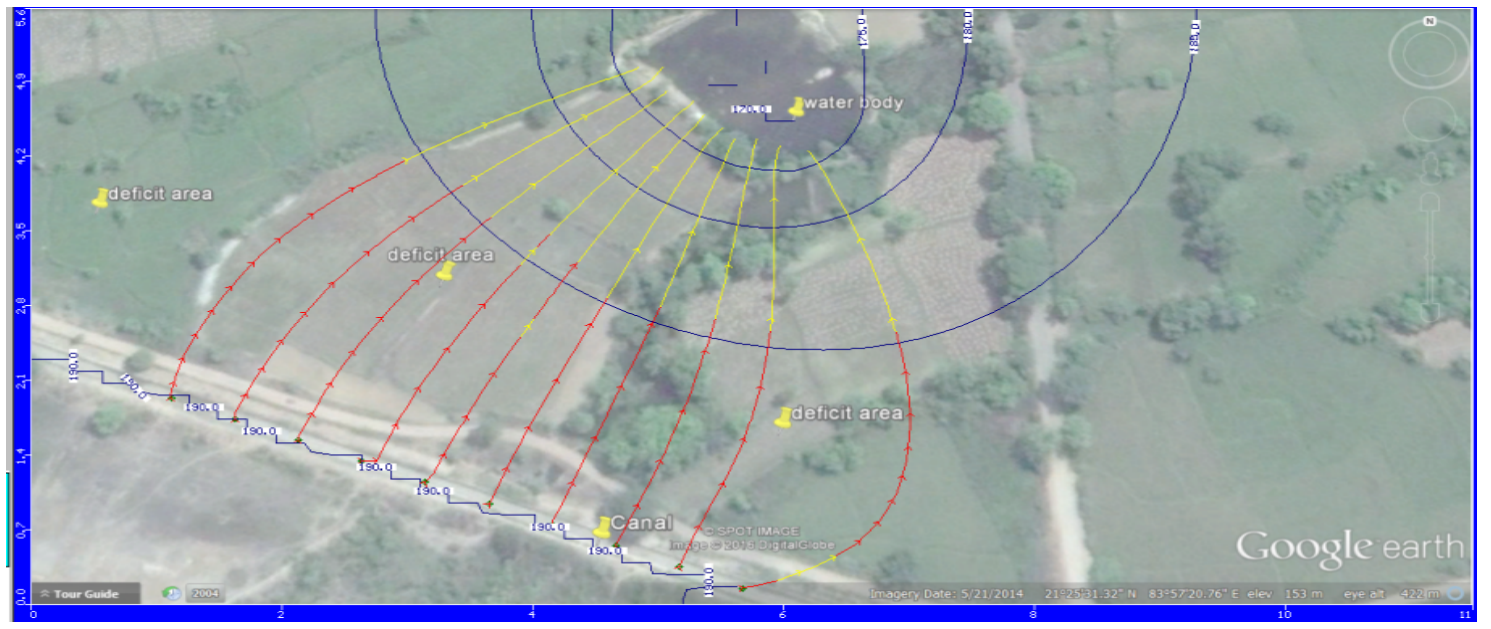

Fig. 7 Flowlines showing groundwater flow lines and deficit areas for supply of water. 


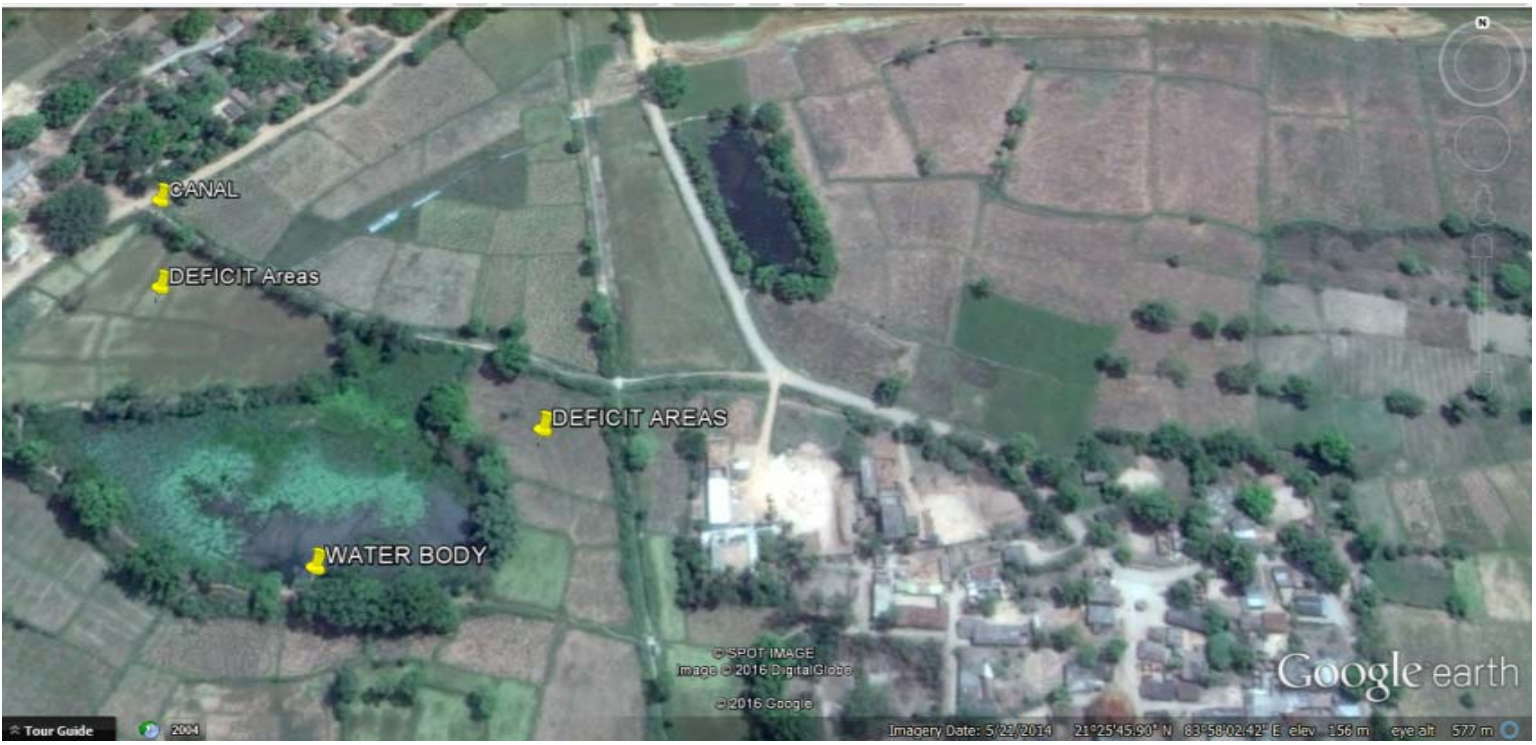

Fig. 8 Imagery view of a area of the Senhapali Distributary

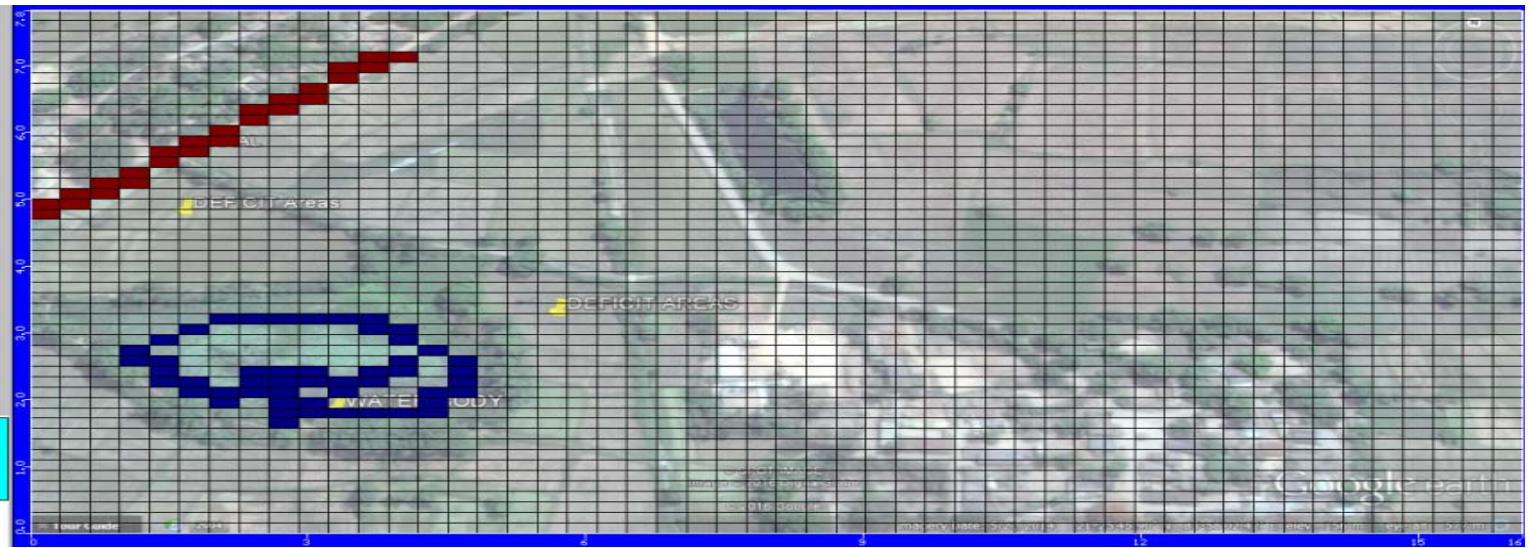

Fig. 9 Constant head and river boundary conditions in the flow mode

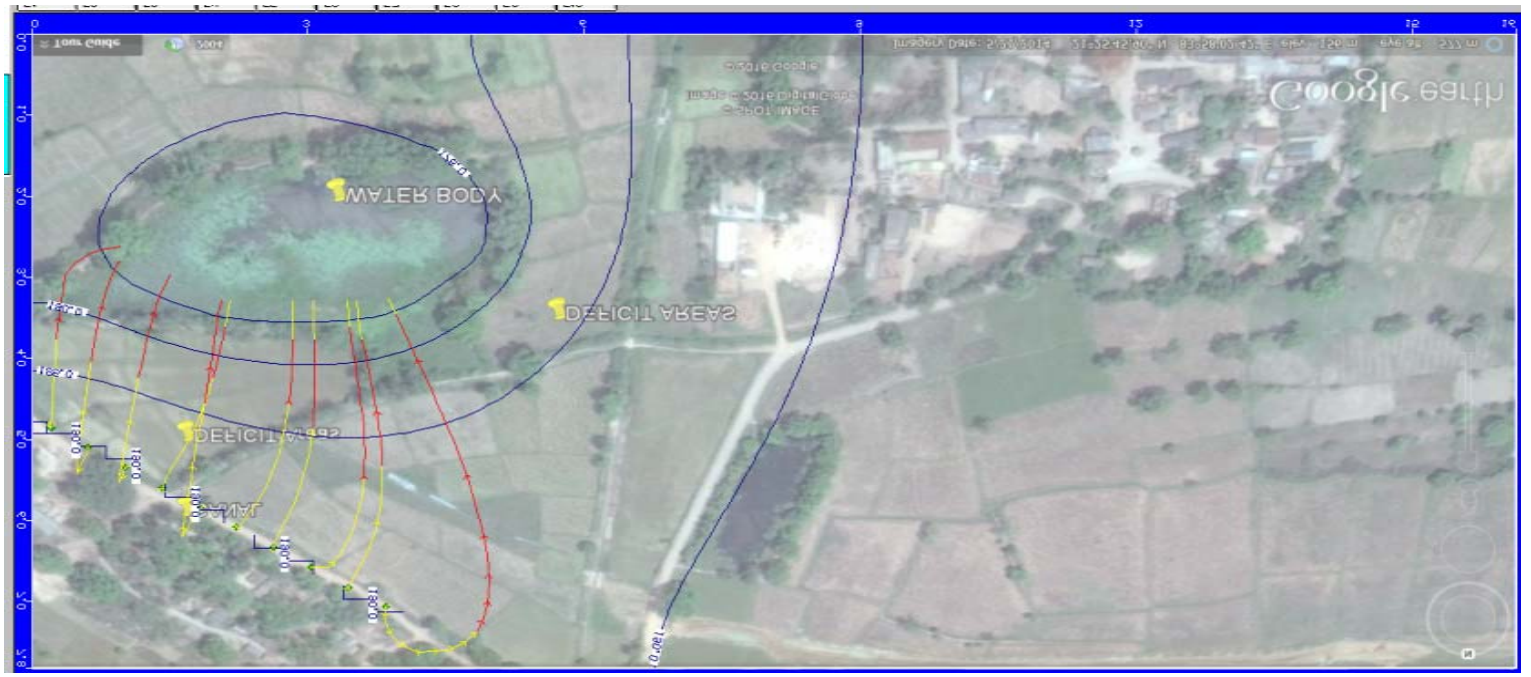

Fig. 10 Flowlines showing groundwater flow lines and deficit areas for supply of water.

The above results shows that areas comprising of Power channel, Chaurnpur minor, Mundoghat minor and Senhapali, all are coming under low land which are having the excess water which will be considered as the waterlogged one. The areas such as Sindurpank are lies in the lowland. Hence, less water means that areas need at least ample amount of water so as for the flow irrigation and different purposes. After river boundaries data has been inputted, the result focuses on the areas where surface water is present. Mahanadi River present in this area in the east helps in providing surface water. 
Path lines shows that the groundwater flow from the power channel towards the Mahanadi river basin, giving the idea to use this excess water present in this so as for the conjunctive use of groundwater and surface water. Conjunctive use of groundwater and surface water means adequate use of groundwater in presence of surface water. Thus conjunctive use can be done in the upland areas in different manner such as by pumping well as it can be easily depicted that where the excess water are present and deficit water are present.

\section{CONCLUSIONS}

Conjunctive use of groundwater and surface water has great impact on the ecosystem .According to this paper, groundwater availability and surface water availability in a part of Hirakud Command Area is assumed to be considered for the conjunctive use management.

$>$ After discussion it has been concluded that in rainy season, there is more availability of the surface water and less availability of groundwater but in case of dry season, there is no availability of surface water but groundwater is utilizing the available water in rainy season.

$>$ According to runoff case in this paper, the runoff is more in monsoon season there are chances of more storage in the ground level in both the cases. Hence, monsoon season is selected as the best season as per the use of groundwater in appropriate amount at the time of need for the irrigation purpose in the part of Hirakud Command Area. Hence conjunctive use of groundwater and surface water act will be done successfully in monsoon as per the average runoff assumed in year between 2004 and 2014.

> After analyzing the groundwater table fluctuation in the areas under Hirakud Command Areas, it has been seen that, the areas under high water table experiencing excess water in case of low water table having less water giving brief on conjunctive use impact in the year between 2004 and 2015.

> After analyzing through Visual MODFLOW, a groundwater flow modeling technique, it has been seen that how the conjunctive use is applied here with a part of Hirakud Command Area that has been taken as study area. It has been conclude that:

* The study have highlighted groundwater condition and particle migration in the shallow unconfined aquifer of the areas of Senhapali Distributary.

* Groundwater model has been conceptualized and developed using the litho logic information and similar aquifer parameters applicable for the region.

* The computed groundwater level contours have shown to replicate the trend of observed groundwater contours.

* It was found that the surface topography controls the groundwater flow condition in the active cells.

* General ground flow direction indicate NW-SE direction along the areas in the active cells.

* After going through the waterlogged areas and deficit areas of low land and upland respectively under Senhapali Distributary, it has been conclude about those areas where to pump well and plant trees so as per the conjunctive use of groundwater and surface water in effective manner.

\section{REFERENCES}

[1] Safavi, H. R., Darzi, F., and Mariño, M. A. Simulation-optimization modeling of conjunctive use of surface water and groundwater. Water resources management, 24(10), 1965-1988. 2010

[2] Rohit Goyal A.N. Arora, Use of Remote Sensing in Ground Water Modeling, Map India Conference 2003.

[3] Sethi, L.N., Kumar, D.N., Panda, Optimal Crop Planning and Conjunctive Use of Water Resources in a Coastal River Basin, Water Resources Management, Volume 16, Issue 2, pp 145-169, April 2002, doi:10.1023/A:1016137726131

[4] Rao, S.V.N., Bhallamudi, S.M., Thandaveswara, B.S., Mishra, G.C.. Conjunctive use of surface and groundwater for coastal and deltaic systems. J. Water Resour. Plann. Manage. 130 (3), 255-267. 2004.

[5] Marques G, Lund JR, Howitt R, Modeling conjunctive use operations and farm decisions with two-stage stochastic quadratic programming. J Water Resour Plan Manage 136(3):386-394, (2010)

[6] Ashfaque Jafari and G Jagmohan Das. Integrated conjunctive use model, ISSN 2319-5991 www.ijerst.com Vol. 2, No. 3, August 131166, 2013.

[7] Saideepa Kumar; Paul Pavelic; Biju George; K. Venugopal - Integrated Modeling Framework to Evaluate Conjunctive Use Options in a Canal Irrigated Area , Journal of Irrigation and Drainage Engineering Volume 139 Issue 9 - September 2013.

[8] K.J.Anandha kumar and S.K.Sinha, groundwater simulation studies in hirakud irrigation command area, orissa, india 


\section{AUTHOR PROFILE}

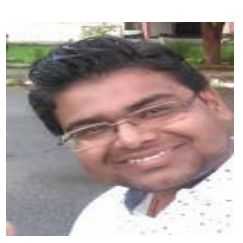

SANDEEP SAMANTARAY, M.tech working as Guest faculty at VSSUT,BURLA, Sambalpur with Water Resource Engineering as Specialization

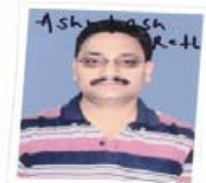

ASHUTOSH RATH, working as Asst. professor at SIT, Sambalpur with Water Resource Engineering as Specialization .Currently pursuing $\mathrm{PhD}$ at VSSUT, BURLA. Two papers published in international journals.

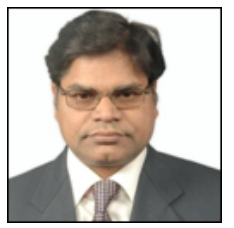

PROF. PRAKASH CHANDRA SWAIN working as, Professor AT VSSUT BURLA. Specialization Water Resources Engineering, Application of Artificial Intelligence Techniques to Water Resources Management.. More than 30International Publications. 